\title{
Corruption in Nigeria: Theoretical Explanation
}

\author{
Olusola O Karimu \\ Center for Juvenile \& Family Studies Inc \\ New York, NY, USA \\ E-mail: olusolakarimu@gmail.com Tel: 234-151-6244-6431
}

Received: March 11, 2016 Accepted: April 1, 2016 Published: June 13, 2016

doi:10.5296/iss.v4i1.9603

URL: http:/dx.doi.org/10.5296/iss. v4i1.9603

\begin{abstract}
The purpose of the current study is to explain corruption from social learning and social disorganization perspectives. The study utilized survey design, participants were selected through convenience sampling and two thousand and fifty six respondents participated in the study. Descriptive statistics such as mean, median, frequency tables and percentages were adopted to analyze the data collected from the field. Both male and female participants, irrespective of their religion perceived that changes in cultural values have increased corruption in Nigeria. Majority of the participants noted that corruption as a behaviour is learned. The findings indicate that social learning and social disorganization theories are relevant in explaining incidents of corrupt practices in Nigeria.
\end{abstract}

Keywords: Nigeria, corruption, corrupt practices, social learning theory, social disorganization theory and Internet survey 


\section{Introduction}

Although in many African countries, including Nigeria, corruption is outlawed (Odemba, 2010), it is nonetheless embedded in society (Anassi, 2004). Obasanjo (2014) noted that corruption remain a major bane of the Nigeria society and despite the fact that it is present in every societies, attempts should be made not to condone it as it carries with it the threat to annihilate a country that is ingrained with corruption. Similarly, it has been noted that societies ridden with corruption will not survive or developed in an orderly fashion (Aluko, 2002; Obasanjo, 2015).

Gbadamosi (2006) noted that Nigeria has been consistently rated one of the most corrupt nations in the world since 2001 by the Transparency International Corruption Perception Index (TICPI). In a World Bank International Monetary Fund (IMF) report, 35 countries, including Nigeria, were listed as corrupt or politically tenuous (as cited in Collier, 2009). According to Madeley (2003), the Corruption Perceptions Index indicates that Nigeria is among the worst eight countries in the world for corruption in government and public administration. Kaufmann, Kraay, and Mastruzzi (2010) reported that fewer than $10 \%$ of African countries rate worse than Nigeria in controlling corruption.

Aluko (2002) charged that corruption has become embedded in Nigerian politics. Its residents see it as an inevitable part of the social system. Alutu (2007) called corruption a "cankerworm that has eaten into the fabric of [Nigerian] soc iety" (p. 393) and predicted that if the war against corruption is not won, sustainable technological development and socialpolitical stability will be impossible. According to Ogundiya (2011), agencies created to improve the quality of life for Nigerian citizens, such as the Niger Delta Development Board (NDDB) and Oil Mineral Producing Areas Development Commission (OMPADEC), failed largely because of corruption and mismanagement.

It is a well-known fact that corruption as a major problem facing Nigeria is widespread and hinders the nation's development by affecting its social and economic institutions (Onwuka, Okoh \& Eme, 2009). Corruption affects all the institutions in Nigeria from the power sector to the education sector (Aluko, 2002). For example, corruption has been noted to have adverse effects on the educational sector by diminishing academic standards and the quality of research (Okebukola, 2013), as well as manpower development (Saint et al., 2003). Okebukola (2013) argued that widespread corruption in Nigeria has seriously undermined public trust in the Nigerian university system and has resulted in production of unqualified graduates for the employment market.

\section{Originality}

Corruption is a complicated phenomenon. Meng and Friday (2010) called it "simultaneously economic, political, criminal and sociological in origin" (p. 1). Zhang, Cao, and Vaughn (2009) argued for criminological and criminal-justice-based research on corruption. They noted that despite the proliferation of studies on corruption most research on corruption comes from such disciplines as economics and political science. From that perspective, they observed, corruption is seen as social and economic issue. Zhang et al. (2009) charged that 
most researchers have failed to see corruption as an outcome rather than a cause and have not analyzed corruption in the light of criminological theory. Meng and Friday (2010) argued that since corruption is a criminal act, it demands an integrated theoretical approach that considers the prevailing criminal justice, economic, political, environment and social norms of a given society. As a result, the current study utilized social learning and social disorganization theories which are important criminological theories of criminal behavior to illuminate on the state of corruption in Nigeria.

The purpose of this endeavor is to utilize social learning and social disorganization theories of crime to explain corruption in Nigeria with the aim of deepening and enhancing an understanding of corruption in Nigeria as a means to identify gaps, resources, concerns, and solutions. Therefore, findings articulated in the current research will provide a better understanding of how corruption thrives and how opportunities are created for people to be corrupt. Results could spur additional research on corruption from other theoretical perspectives in criminology and criminal justice. Furthermore, the current endeavor can prompt a reevaluation of programs and laws that address corruption in the light of ongoing revelations of widespread corruption in Nigeria (Aderonmu, 2011; Aluko, 2002; Dike, 2002; 2003; Odemba, 2010).

\section{Social Learning and Social Disorganization Theories}

Social learning theory (SLT) and social disorganization theory (SDT) can be adequately utilized as lens to view the institutionalization of corruption in Nigeria and how corruption has affected values and behavioral norms. These theories help explain the behavioral and environmental determinants that facilitate corruption, as well as the social environment within which corruption operates in Nigeria (Akers \& Sellers, 2009). Ocheje (2001) noted that that both behavioral and environmental issues are important when discussing corruption because they determine whether anticorruption measures will succeed or fail.

\section{Social Learning Theory (SLT)}

Social learning theory has been used by some researchers to explain criminal behavior (Sandholtz \& Taagepera, 2005). The theory is based on the assumption that a similar learning process can produce both deviance and conformity. Four variables are thought to influence social behavior: definitions, differential association, modelling, and reinforcement. The interaction of these variables predisposes one to either conforming or deviant behaviour (Singer \& Hensley, 2004; Tittle, 2004).

According to social learning theory, behavior is influenced by standards of legal and illegal behavior, peers, and positive or negative reinforcement. A key variable is differential association, or peer influence. Definitions of deviance are developed in interactions with peers and are reinforced, positively or negatively, by rewards and punishments. Those definitions affect attitudes and behavior in many areas: sexual behavior, substance use, white-collar crime, and so forth (Akers \& Sellers, 2009).

Bernard, Snipes, and Gerould (2010) characterized social learning theory as acknowledgement that learning involves an interplay of environmental, behavioral, and 
cognitive influences. Criminal or deviant behavior, then, results in part from the observation of consequences that particular behaviors have for other people (Akers \& Sellers, 2009). Although social learning theory addresses potential influences on criminal behavior, it does not address the particular environments that create such behavior. Bernard et al. (2010) suggested that social structure affects crime because it affects one's exposure to norms and the consequences of violating norms. Similarly, Bandura's research on social learning showed how the way crime is portrayed in mass media can affect criminal behavior (Wiesner, Capaldi, \& Patterson, 2003).

Social leaning theorists argue that behavior is influenced by one's self-concept, one's social role, and how one perceives a social situation (Sandholtz \& Taagepera, 2005). Each of these, in turn, is the product of the socialization that occurs at the institutional level (Meng \& Friday, 2010). A social problem such as corruption, then, is affected not only by material incentives but also by cultural orientations, which are the result of socialization (Meng \& Friday, 2010; Sandholtz \& Taagepera, 2005; Travits, 2010).

According to Aluko (2002), despite the fact that social learning theory has been extensively studied, efforts to examine the mechanisms linking social structure to corruption and its effects on social attitudes have been lacking. The result is poor understanding of how particular social conditions lead to corrupt practices. The current study helped test the utility of social learning theory by applying it to an analysis of Nigerians' perceptions of corruption and how those perceptions are determined by their social role and definition of corrupt practices.

Travits (2010) found that for citizens and public officials, the decision whether to engage in corruption is mostly affected by individuals' definitions of corruption and personal perceptions of how widespread corruption is. Travits (2010) noted that research by political scientists and economists has addressed cross-national differences of perceptions of corruption. This research has focused mostly on structural features, with less emphasis on why some officials are more susceptible to corrupt behavior than others. Based on social learning theory, corruption, although socially influenced, is ultimately a result of individual choices. Although institutions and systems can be restructured, if individual motivations are not taken into account, restructuring may be difficult to achieve.

Tittle (2003) linked broad social structural conditions to individual learning. A subculture of deviance is transmitted intergenerationally through beliefs, values, and attitudes. Social learning theory, then, proposes that a willingness to engage in corruption reflects an acquired belief that it is not morally wrong but rather is an acceptable form of behavior. Although social learning theory has been influential in criminological circles, it has been used mostly to explain crime and delinquency in general rather than corruption specifically (Chappell \& Piquero, 2004).

\section{Social Disorganization Theory}

Social disorganization theory (SDT) originated as part of the Chicago School, a body of work focusing on urban sociology in the 1920s and 30s (Bernard, Snipes, \& Gerould, 2010). Social 
learning theory belongs to a tradition of studying problems in light of the social processes that bring them about. The theory is based on the assumption that behavior is influenced primarily by one's environment, and that corruption and other deviant and criminal behavior are a result of weakened mechanisms of social control (Steenbeek \& Hipp, 2011). The theory has been applied to how antisocial attitudes develop in individuals, families, and communities, and how those attitudes conflict with larger social norms (Johnson, 1998).

According to social disorganization theory, dysfunctional behavior has cultural, political, and economic causes (Akers \& Sellers, 2009). Established communities experience increases in deviance and crime when their way of life and the established order change. Disorganized communities experience crime because informal social controls break down, resulting in the emergence of deviance and criminal cultures. Such communities lack the collective efficacy to fight crime and disorder (Hochstetler \& Copes, 2008; Vito, Maahs, \& Homes, 2007). The theory predicts that more crime will occur in neighborhoods with fraying social structures, such as failing schools, vacant or vandalized buildings, changing ethnicity, and high unemployment (Steenbeek \& Hipp, 2011).

The sociological perspective out of which social learning theory emerged does not consider specific behavior as a problem of an individual but instead considers individual behavior as reflecting the social order in which an individual lives. This assumption agrees with Durkheim's notion that all behavior is socially generated. In this view, a particular social problem such as corruption must be addressed by focusing on a society, not a particular individual's behavior (Steenbeek \& Hipp, 2011). Johnson (1998) used social disorganization theory to argue that in many nations corruption is embedded in the overall society. In these countries, economic and political processes perpetuate corruption rather than resist it. Consistent with the assumptions of social disorganization theory, corruption can be reduced by developing enhanced criminal justice, political, social, and economic institutions, which will bring about social empowerment (Colombatto, 2003; Johnson, 1998).

\section{Theoretical Synthesis}

From the social learning perspective, corrupt practices and behavior are transmitted in a learning process (Colombatto, 2003). Social learning theory predicts that the likelihood of punishment will influence citizens' decision whether to engage in corrupt practices. The theory also assumes that corrupt practices among government officials university students and in Nigeria as a whole are a result of a corruption subculture that provides an opportunity to learn corruption and deviant activities (Aluko, 2002; Colombatto, 2003). Social learning theory assumes that favorable attitudes towards corruption are a result of immediate material incentives and prevailing sociocultural orientations (Meng \& Friday, 2010).

Social disorganization theory has been applied to how antisocial attitudes develop in individuals, families, and communities, and how those attitudes conflict with larger social norms (Johnson, 1998). It emphasizes that corruption and other societal vices reflect an enabling subculture (Aluko, 2002). From the social disorganization perspective, in studying corruption, one's self-concept and definition of the situation are the main forces determining one's attitude, perception, and behavior, and these individual characteristics are the products 
of socialization at the societal and institutional levels. Adindu (2010) noted that the extent of corruption among, for example, university students is a reflection of the society in which they live. Corruption should therefore be expected to be widespread among university students because of the weak accountability system in Nigeria's educational system and the fact that the larger society tolerates such practices (Okebukola, 2013).

\section{Study Methodology}

The purpose of the current research is to explain corruption in Nigeria from the social leaning and social disorganization perspectives. Survey is the preferred type of data collection for the study due to the economy of the design and the rapid turnaround in data collection (Copuer \& Mille, 2008; Lindhjen \& Navrud, 2011). The chosen design provides a quantitative representation of behavior and opinions through sampling of a population (Couper \& Mille, 2008; Creswell, 2009).

The study participants were selected through convenience sampling because it is extremely fast, easy, readily available, and cost effective, causing it to be an extremely attractive option to most researchers (Leedy \& Ormrod, 2010). The site from which the sample for this study was drawn was a community in a Southwestern, Nigeria. Potentials participants were recruited through flyers. Flyers were posted in strategic locations in the community. This study employed an Internet survey, which as a model of inquiry is appropriate for understanding the attitudes and perceptions of a specific population.

Internet surveys - compared to face-to-face, telephone, and mail surveys-have the advantage of being cheaper, faster, and independent time and space (Blasius \& Brandt, 2010). Internet research provides researchers with great advantages for sampling and data collection, especially when a study focuses on sensitive topics or the population is hard to reach (Alessi \& Marti, 2010; Hash \& Spencer, 2009). The researcher distributed an online, closed-ended questionnaire with 30 item: demographic questions and Attitude Towards Corruption scale created by Gbadamosi and Bello (2009). The instrument was modified to obtain relevant data from the sample in the current study. Total of two thousand and fifty-six $(2,056)$ respondents completed the survey. Descriptive statistics such as simple percentage, frequency distribution, median, and mean were used to identify the utility of social disorganization and social learning perspectives to explaining corruption in Nigeria. Data analyses involved in-depth comparisons between question sets to identify trends or relationships, cross-tabulations, filters, and SPSS analytical tools. 
8. Discussion of Findings

Table 1. Descriptive statistics for corruption explanation in Nigeria

\begin{tabular}{|c|c|c|c|c|c|c|c|c|c|}
\hline \multirow[t]{2}{*}{ Innovation Barrier } & \multirow[t]{2}{*}{ Number } & \multicolumn{2}{|c|}{ Neutral } & \multicolumn{2}{|c|}{$\begin{array}{c}\text { Strong } \\
\text { Disagree/Disagree }\end{array}$} & \multicolumn{2}{|c|}{$\begin{array}{c}\text { Strongly } \\
\text { Agree/Agree }\end{array}$} & \multirow[t]{2}{*}{ Mean } & \multirow[t]{2}{*}{ S.D } \\
\hline & & Freq. & $\%$ & Freq. & $\%$ & Freq. & $\%$ & & \\
\hline $\begin{array}{l}\text { Rate of bribery and corruption } \\
\text { is high in Nigeria }\end{array}$ & 2056 & 58 & $2.82 \%$ & 87 & $4.23 \%$ & 1911 & $92.95 \%$ & 685.33 & 1061.56 \\
\hline $\begin{array}{l}\text { People become corrupt because } \\
\text { they learned the behavior }\end{array}$ & 2056 & 48 & $2.33 \%$ & 67 & $3.26 \%$ & 1941 & $94.41 \%$ & 685.33 & 1087.48 \\
\hline $\begin{array}{l}\text { Public officials who associated } \\
\text { with those who are corrupt will } \\
\text { also engage in corrupt practices }\end{array}$ & 2056 & 58 & $2.82 \%$ & 87 & $4.23 \%$ & 1911 & $92.95 \%$ & 685.33 & 1061.56 \\
\hline $\begin{array}{l}\text { Corruption is a major problem } \\
\text { in this country }\end{array}$ & 2056 & 48 & $2.33 \%$ & 67 & $3.26 \%$ & 1941 & $94.41 \%$ & 685.33 & 1087.48 \\
\hline $\begin{array}{l}\text { Bribery and corruption is } \\
\text { common in this country }\end{array}$ & 2056 & 63 & $3.06 \%$ & 52 & $2.53 \%$ & 1941 & $94.41 \%$ & 685.33 & 1087.45 \\
\hline $\begin{array}{l}\text { Changes in cultural values have } \\
\text { increased corruption in this } \\
\text { country }\end{array}$ & 2056 & 485 & $23.59 \%$ & 415 & $20.18 \%$ & 1156 & $56.23 \%$ & 685.33 & 409.11 \\
\hline $\begin{array}{l}\text { Corruption is culturally } \\
\text { acceptable in this country }\end{array}$ & 2056 & 291 & $14.15 \%$ & 1190 & $57.88 \%$ & 575 & $27.97 \%$ & 685.33 & 459.54 \\
\hline $\begin{array}{l}\text { Lack of sanctions for corrupt } \\
\text { practices is likely to increase } \\
\text { corruption }\end{array}$ & 2056 & 124 & $6.03 \%$ & 130 & $6.32 \%$ & 1802 & $87.65 \%$ & 685.33 & 967.07 \\
\hline $\begin{array}{l}\text { Corruption can never be } \\
\text { eliminated in this country }\end{array}$ & 2056 & 255 & $12.40 \%$ & 1219 & $59.29 \%$ & 582 & $28.31 \%$ & 685.33 & 490.24 \\
\hline $\begin{array}{l}\text { The Nigeria society appreciates } \\
\text { public official who do not } \\
\text { engage in corrupt practices }\end{array}$ & 2056 & 360 & $17.51 \%$ & 580 & $28.21 \%$ & 1116 & $54.28 \%$ & 685.33 & 388.85 \\
\hline $\begin{array}{l}\text { Citizens of this country are } \\
\text { generally not corrupt } \\
\text { individuals }\end{array}$ & 2056 & 463 & $22.52 \%$ & 845 & $41.10 \%$ & 748 & $36.38 \%$ & 685.33 & 198.56 \\
\hline
\end{tabular}

Source: Field report, 2015

The analysis of the socio-economic characteristics of the participants shows that 2056 respondents completed the survey. Majority of the participants for this study $1249(60.7 \%)$ were male while 807 (39.3\%) were female respondents. Those who indicate that Christianity is there religion are in the majority as they constitute $1202(58.5 \%)$ of the total 
population of the study participants while $854(41.5 \%)$ respondents indicated that Islam is their religion. As contained in the above table, majority of the respondents 1911 (92.95\%) either strongly agreed or agreed that the rate of bribery and corruption is high in Nigeria while only $87(4.23 \%)$ either strongly disagreed or disagreed that it is high. Also, $1,941(94.41 \%)$ respondents strongly agreed or either agreed that corrupt behavior is learned with 67 (3.26\%) either strongly disagreed or disagreed. Similarly, 1,911(92.95\%) either strongly agreed or agreed that public officials in Nigeria who associate with those who are corrupt will also engage in corrupt practices. Those who either strongly disagreed or disagreed constitute $87(4.23 \%)$ of the total respondents while $58(2.82 \%)$ percent respondents were neutral in their answer. As reported by 1, 941 (94.4\%) of the respondents, which constitute the majority, corruption has become a major problem in Nigeria.

Another question answered by the respondents is whether changes in cultural values have increased the rate or level of corruption in Nigeria. Majority of the respondents 1, 156 $(56.23 \%)$ either strongly agreed or agreed that it has increase corruption in Nigeria while 415 $(20.2 \%)$ either strongly disagreed or disagreed that changes in cultural values have increased corruption in the country. The table also indicate that 485 (23.59\%) respondents were neutral with regards to the question. From the same perspective, 575(27.95\%) of the respondents were of the opinion that that corruption is culturally acceptable in Nigeria while majority of the respondents representing $1,190(57.88 \%)$ either strongly disagreed or disagreed that it is culturally acceptable in the country and the remaining $291(14.15 \%)$ were neutral in their response. The above table also indicate that $1802(87.65 \%)$ either strongly agreed or agreed that lack of sanction from different levels of government in Nigeria is likely to increase the rate of corruption while $130(6.32 \%)$ either strongly disagreed or disagreed with 124 respondents $(6.03 \%)$ represented those who were neutral in the response.

The participants were also asked whether they feel that corruption can never be eliminated in Nigeria, 582 respondents $(28.31 \%)$ either strongly agreed or agreed that it can never be eliminated, $1219(59.29 \%)$ either strongly disagreed or disagreed and held to the opinion that corruption can indeed be eliminated in the country. Respondents who neutral in the response were $255(12.4 \%)$. Most of the participants of the current study 1,116 (54.28\%) either strongly agreed or agreed that the Nigeria society appreciates public official who do not engage in corrupt practices, those who either strongly disagreed or disagreed were 580 $(28.21 \%)$ and the remaining 360 ( $17.51 \%)$ participants were neutral in their response. Additionally, 748 (36.38\%) respondents were of the opinion that Nigeria citizens are generally not corrupt individuals, those who either strongly disagreed or disagreed represent $845(41.10 \%)$ and the remaining $463(22.52 \%)$ were neutral in their response.

A critical assessment of the participants' responses indicate that the arguments of both social learning and social disorganization theories are relevant in explaining the perceived widespread corruption in Nigeria (Aluko, 2002; Dike, 2003). Therefore, explaining rampant cases of corrupt practices in the country from the perspectives of social learning and social disorganization theories are valid and important because of the potentials of illuminating on how corruption affects both leadership and followership behavior and performance at different levels of Nigerian society. This study therefore provides additional support for 
social learning and social disorganization theories as explanation for the widespread corruption in Nigerian society. According to Peterson and Krivo (2005), despite critical consensus that structural disadvantages are a major contributor to crimes such as corruption, there is less agreement about how such factors operate to produce corruption and how they affect people's opinions and attitudes.

Both male and female participants of the current study perceived that changes in cultural values have increased corruption in Nigeria and that corruption is culturally acceptable in country. Male and female participants, irrespective of their religion, agreed that corruption is a major problem in Nigeria. The results demonstrated that there was no significant difference in perceptions of male and female participants on these items. Additionally, the vast majority of respondents across all variables perceived that corruption is increasing, that bribes and tips are expected in daily life, and that a committed government could reduce corruption in Nigeria.

The findings of the current research confirmed the belief that lack of stiff punishment and the low risk of being caught predispose people to engage in corruption. Overall, this study enlarges an understanding of the dynamics of corruption in Nigeria, and it helps refine both social learning and social disorganization theories of criminal behavior while also contributing to the literature on compliance and ethical behavior.

\section{Discussion of Results in Relation to the Literature and the Field}

Studies on corruption have suggested that social structure influences crime by affecting one's exposure to norms and norm violation. Similarly, Bandura's research on social learning showed that the way crimes such as corruption are portrayed in mass media can affect criminal behavior (Wiesner et al., 2003). Most researchers see corruption as a social problem that is influenced by a society's historical and cultural heritage (Meng \& Friday, 2010; Sandholtz \& Taagepera, 2005; Travits, 2010). Research on corruption has shown that it is influenced by individual definitions of corruption and perceptions of how widespread corruption is (Travits, 2010). According to social learning theory, corruption, although socially influenced, is primarily the result of individual decisions. Although institutions and political systems can be restructured, that process may not be effective if individual motivations for corrupt behavior are not understood.

Social disorganization theory assumes that corruption is institutionalized in some societies because it becomes normalized. Research employing social disorganization theory in the analys is of corruption includes Aluko's (2002) study of institutionalization of corruption in Nigeria, Colombatto's (2003) study of why corruption is tolerated in some societies, and Johnson's (1998) research on fighting systemic corruption and institutional reform. These authors suggested that institutionalizing corruption can change a society's norms and value system. Corruption, then, should be viewed as essentially a social problem conditioned by the structure of a given society and not as resulting from individual disposition. These conclusions suggest that corruption is a major problem in Nigerian society due to the fact that it has been internalized and institutionalized. 


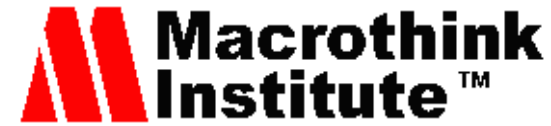

Several factors help explain the current study's findings. For example, Shehu (2004) suggested that unemployment, poverty, and inadequate social supports have led to high incidences of corruption and other crimes in Nigeria. Other explanations include the prolonged military intervention in Nigeria and a weak criminal justice system (Kaufman, 2003). The current study's results could have been influenced by the fact that terms used in the questionnaire, such as bribery and corruption, are closely related. Lambsdorff (2008) suggested that distinctions should be made among different forms of corruption, such as nepotism, which the instrument did not do. Also, the current study is an example of descriptive research focused on understanding behavior and perceptions in a single location. As a result, it used a homogenous sample (one location in a southwestern Nigeria state) to explain the prevalence of corruption in Nigeria.

\section{Limitations}

Several limitations are worth noting: The fact that this research utilizes participants from one location serve as a weakness. Also, since the study was confined to a single location in southwestern Nigeria, it is therefore suggested that future research on corruption attempt to engage participants from different locations. This research was designed to examine the relevance of both the social learning and social disorganization models to explaining corruption in Nigeria. Other important issues (e.g., the work of anticorruption agencies, challenges political leaders face in addressing corruption in Nigeria, and corruption in other African countries) are worthy of study but were beyond the scope of the current study.

\section{References}

Aderonmu, J. A. (2011). Civil society and anti-corruption crusade in Nigeria's fourth republic. Journal of Sustainable Development in Africa, 13(1), 75-86.

Adindu, A. (2010). Student's perception about the effect of corruption on quality of health care. International Journal of Biological Sciences, 2(7), 122-127.

African Union. (2008). African union convention on combating and preventing corruption. Retrieved from http://journals.cambridge.org/production/action/cjoGetFulltextfulltextid $=311403$

Akers, R. L., \& Sellers, C. S. (2009). Criminology theories (5th ed.). NY: Oxford University Press.

Alessi, E. J., \& Martin, J. I. (2010). Conducting an Internet-based survey: Benefits, pitfalls, and lessons learned. Social Work Research, 34(2), 122-128.

Aluko, M. (2008). The global financial meltdown: Impact on Nigeria's capital market and foreign reserves. Retrieved January 14, 2012, from http://www.google.com on

Aluko, M. A. O. (2002). The institutionalization of corruption and its impact on political culture and behavior in Nigeria. Nordic Journal of African Studies, 11(3), 393-402. 
Alutu, O. E. (2007). Unethical practices in Nigeria construction industry: Prospective engineers' viewpoint. Journal of Professional Issues in Engineering Education and Practices. http://dx.doi.org/10.1061/(ASCE)1052-3928(2007)133:2(84)

Anassi, P. (2004). Corruption in Africa. The Kenyan experience. Victoria, Canada: Trafford.

Bernard, T. J., Snipes, J. B., \& Gerould, A. L. (2010). Vold's theoretical criminology (6th ed.). York, NY: Oxford University Press.

Blasius, J., \& Brandt, M. (2010). Representatives in online surveys through stratified samples. Bulletin de Methodologie Sociologique, 107, 5-21.

Chappell, A. T., \& Piquero, A.T. (2004). Applying social learning theory to police misconduct. Deviant Behavior, 25, 89-108.

Collier, P. (2009). War guns and votes: Democracy in dangerous places. New York, NY: Harper Collins.

Colombatto, E. (2003). Why is corruption tolerated? Review of Australian Economics, 16(4), 363-379.

Couper, M., \& Mille, P. (2008).Web survey methods. Introduction. Public Opinion Quarterly, 72(5), 831-635.

Dike, V. E. (2002). The state of education in Nigeria and the health of the nation in the Nigeria Economic Summit Group. Online Publication, Africa Economic Analysis, Retrieved July 24, 2012, from http://www.afbis.com/analysis/education10204234737.htm

Dike, V. E. (2003). Managing the challenges of corruption in Nigeria. Center for Social Justice and Human Development (CSJHD). Retrieved from http://www.ebscohost.comlibrary.capella.edu

Gbadamosi, G. (2006). Corruption perception and sustainable development: Sharing Botswana's anti-graft agency experiences. South Africa Journal of Economics and Management Studies, 9(2), 262-276.

Gbadamosi, G., \& Bello, M. (2009). The kings new clothes in the eyes of the beholder: Developing a measurement scale for attitude towards corruption. In E. Kaynak, \& T. D. Harcard (Eds.), Measurement challenges in an environment of increasing regional and global concerns. Proceedings of the $18^{\text {th }}$ World Business Congress, 1-15 July, Tbilisi, Georgia, 73-78.

Hash, K. M., \& Spencer, S. M. (2009). You've got subjects: The promise of the Internet in research with lesbian, gay, bisexual, and transgender populations. In W. Meezan, \& J. I. Martin (Eds.), Handbook of research with gay, lesbian, bisexual, and transgender populations (pp. 238-258). New York, NY: Routledge.

Hochester, A., \& Copes, H. (2008). Where I'm from: Criminal predators and their environment. Boston, MA: Jones and Bartlett. 
Johnson, M. (1998). Fighting systemic corruption: Social foundations for institutional reform. European Journal of Research, 10(1), 85-105.

Kaufman, D., Kraay, A., \& Mastruzzi, M. (2010). The worldwide governance indicators: Methodology an analytical issues. Retrieved from http://www.info.worldbank.org /governance

Lambsdorff, J. G (2008). The methodology of the Corruption Perception Index. Transparency International (TI) and University of Passau.

Leedy, P. D., \& Ormrod, J. E. (2010). Practical Research: Planning and Design (9th ed.). Upper Saddle River, NJ: Pearson Education, Inc.

Lindhjem, H., \& Navrud, S. (2011). Are Internet surveys an alternative to face-to-face interviews in contingent valuation? Ecological Economics, 70, 1628-1637.

Madeley, J. (2003, September). Corruption-its effect. Appropriate Technology, 30(3), 28-29. ABI/INFORM Global.

Meng, Q., \& Friday, P .C. (2010). Corruption in transitional China: A theoretical conceptualization. In V. Konarska, \& J. Lachowski (Eds.), Major problems of contemporary criminal law, criminology and victimology. Wolterskluwer Publishing Office, Polish Branch.

Obasanjo, O. (2014). My watch: Now and then. Nigeria: Kachifo Limited.

Ocheje, P. D. (2001). Law and social change: A socio-legal analys is of Nigeria's Corrupt Practices and Other Related Offences Act, 2000. Journal of African Law, 45(2), 173-195. Retrieved from http//www.jstor.org/stable/3558954

Odemba, A. S. (2010). Corruption in sub-Sahara Africa: A phenomenological study (Unpublished doctoral dissertation). Retrieved from http://www.ebscohost.comlibrary. capella.edu

Ogundiya, I.S. (2011). Beyond the "geography of terrorism and terror of geography" Thesis: corruption and the development tragedy in the Niger Delta Region. Journal of Developing Societies, 27, 57-91. http://jds.sagepub.com/content/27/1/57

Okebukola, P. (1998). Management of higher education with special reference to Nigeria. In UNESCO Regional Office for Africa, Higher education in Africa: Achievements, challenges and prospects (pp. 297-321). Dakar, Senegal: BREDA.

Onwuka, C. C., Okoh, C. I., \& Eme, O. I. (2009). Corruption in Nigeria: Nature, forms and challenges before anti-corruption agencies. Interdisciplinary Journal of Contemporary Research in Business, 1(8), 114-133. Retrieved from http://www.Ijcrb.webs.com

Peterson, R. D., \& Krivo, L. J. (2005). Macrostructural analyses of race, ethnicity, and violent crime: Recent lessons and new directions for research. Annual Review of Sociology, 31, 331-356. http://dx.doi.org/10.1146/annurev.soc.31.041304.122308 


\section{Macrothink}

Issues in Social Science ISSN 2329-521X 2016, Vol. 4, No. 1

Saint, W., Hartnett, T. A., \& Strassner, E. (2003). Higher education in Nigeria: A status report. Higher Education Policy, 16, 259-281. http://dx.doi.org/10.1057 /palgrave.hep.8300021

Sandholtz, W., \& Taagepera, R. (2005). Corruption, culture, and communism. International Review of Sociology, 15(15), 109-131.

Shehu, A.Y. (2004). Combating corruption in Nigeria - bliss of bluster? Journal of Financial Crime, 12(1), 69-87.

Singer, S. D., \& Hensley, C. (2004). Applying social learning theory to childhood and adolescent fire-setting: Can it lead to serial murder? International Journal of Offender Therapy and Comparative Criminology, 48, 461. http://www.ijo.sagepub.com

Steenbeek, W., \& Hipp, J .R. (2011). A longitudinal test of social disorganization theory: Feedback effects among cohesion, social control, and disorder. Criminology, 49(3), 833-871.

Tittle, C. R. (2004). Social learning theory and the explanation of crime: A guide for new century. Contemporary Sociology: A Journal of Reviews, 33(6), 716.

Travits, M. (2010). Why do people engage in corruption? The case of Estonia. Social Forces, $88(3), 1257-1279$.

Vito, G., Maahs, J., \& Homes, R. (2007). Criminology: Theory, research, and policy (2nd ed.). Boston, MA: Jones and Barrlett.

Wiesner, M., Capaldi, D. M., \& Patterson, G. R. (2003). Development of antisocial behavior and crime across the life-span from a social interactional perspective: The coercion model. In R. L. Akers \& G. F. Jensen (Eds.), Social learning theory and the explanation of crime: A guide for the new century. Advances in Criminological Theory (Vol. 11, pp. 317-337). Piscataway, NJ: Transaction.

Zhang, Y., Cao, L., \& Vaughn, M. (2009). Social support and corruption: Structural determinants of corruption in the world. Australian and New Zealand Journal of Criminology, 42(2), 204-217. 